Journal of Asian Scientific Research

$\operatorname{ISSN}(e): \quad 2223-1331$

$\operatorname{ISSN}(p):$ 2226-5724

DOI: 10.18488/journal.2.2021.114.42.49

Vol. 11, No. 4, 42.49

(C) 2021 AESS Publications. All Rights Reserved.

URL: wrw.aessweb.com

\title{
HIGH COD AND TURBIDITY REMOVAL IN THE TREATMENT OF POLLUTED POND WATER USING LOW DOSAGE OF PINEAPPLE LEAF COAGULANT: A PRELIMINARY STUDY
}

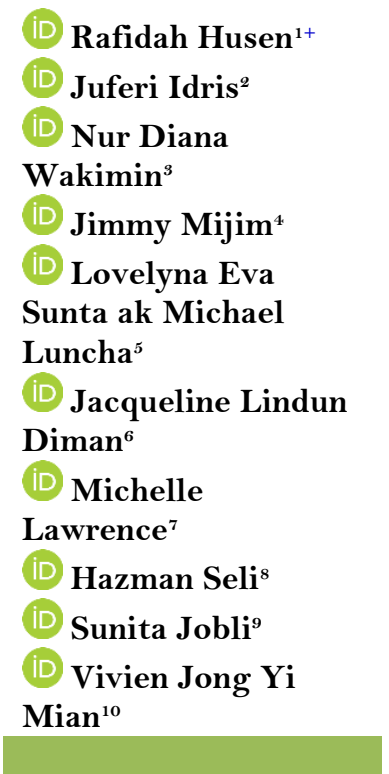

Article History

Received: 18 August 2021 Revised: 20 September 202 Accepted: 26 October 2021 Published: 23 November 2021

\section{Keywords}

Coagulation

COD

Turbidity

Pineapple leaf coagulant

Pond water

Waste utilization.

\author{
${ }^{1, t}$ Faculty of Applied Sciences, Universiti Teknologi MARA (UiTM), \\ Sarawak Branch, Samarahan 2 Campus, Kota Samarahan, Sarawak, \\ Malaysia. \\ 'Email:rafidahh@uitm.edu.my Tel: +60198780478 \\ ${ }^{10}$ Email:vivien@uitm.edu.my Tel: +60 165758037 \\ 2,3,4,5,6,7,9,9 Faculty of Chemical Engineering, College of Engineering, Universiti \\ Teknologi MARA (UiTM), Sarawak Branch, Samarahan Campus, Kota \\ Samarahan, Sarawak; Faculty of Chemical Engineering, College of \\ Engineering, Universiti Teknologi MARA (UiTM), Shah Alam, Selangor, \\ Malaysia. \\ Email:juferi@uitm.edu.my Tel: +60128927419 \\ ${ }^{3}$ Email:nurdiana@uitm.edu.my Tel: +60133690179 \\ Email: geraldjimmymijim@gmail.com Tel: +60 14.5754.111 \\ ${ }^{5}$ Email: lovelynaeva.sunta@gmail.com Tel: +60 109855094 \\ ${ }^{6}$ Email: lindunjacqueline@gmail.com Tel: +60 138360608 \\ 'Email: michellelawrw96@gmail.com Tel: +60 13884.9362 \\ ${ }^{8}$ Email: hazmanseli@uitm.edu.myTel: +60138207337 \\ ${ }^{9}$ Email: sunita@uitm.edu.my Tel: +60 109333510
}

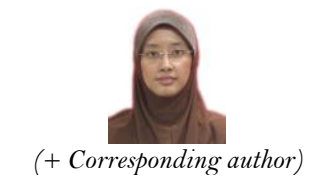

\section{ABSTRACT}

Coagulation process using low dosage of plant-based coagulant to remove high chemical oxygen demand (COD) and turbidity is important for water treatment. This study presents the treatment of pond water using plant-based pineapple leaf coagulant to achieve high COD and turbidity removal. The coagulation was performed using a jar test experiment of pond water at different $\mathrm{pH}$ followed by different dosages of pineapple leaf coagulant. It was found that the highest COD and turbidity removal ranged between $94.1-94.6 \%$ and $88.3-88.4 \%$ at $\mathrm{pH} 8$ respectively, using low dosage $(50 \mathrm{mg}$ $\left.\mathrm{L}^{-1}\right)$ of pineapple leaf coagulant. The final COD and turbidity values ranged between 7.3 - 8.0 $\mathrm{mg} \mathrm{L}^{-1}$ and $17.7-17.8$ formazin turbidity unit (FTU) respectively, which are lower compared with results from other studies that used high dosage coagulants. Moreover, the final $\mathrm{pH}, \mathrm{COD}$, turbidity, dissolved oxygen (DO), and total suspended solid (TSS) values of the treated pond water were below the standard limits set by the National Water Quality Standards for Malaysia (NWQSM) class IIB, which represents water bodies suitable for recreational use with body contact (DOE, 2016). Therefore, it is expected that the newly-formulated waste utilisation of pineapple leaf coagulant can reduce the usage of chemical coagulants and can further be used for different types of water. 
Contribution/ Originality: This study contributes to the newly-formulated environmental friendly coagulant from pineapple leaf. The findings of this study are beneficial for the water industry to achieve optimum removal of $\mathrm{pH}, \mathrm{COD}$, turbidity, DO, and TSS values of treated water using this coagulant to ensure full compliance with the standards and preserving the environment.

\section{INTRODUCTION}

World population is experiencing a continuous growth and is estimated to be approximately 7.4 billion in 2016 [1]. Due to the overgrown population, wastewater production will also increase significantly and it will be channeled either directly or indirectly into water sources such as seas, rivers, lakes, or ponds [2, 3]. Among all water sources available, ponds and lakes are expected to receive the worst impacts because of their size and static water properties [4]. Due to their small size, ponds require better water treatment by aerobic, anaerobic, or coagulation method as they contain organic and inorganic matters [5].

Coagulation treatment has been widely studied as an alternative method to treat polluted water [6]. Coagulation treatment is a turbidity removal process in water by combining small particles into flocs using chemical or natural coagulants. However, chemical coagulants have long been associated with high procurement costs as well as having detrimental effects on human health and environment [7]. Natural coagulants have been found to replace chemical coagulants due to their abundance and safeness. Many studies have been carried out using plant-based coagulants such as dragon fruits, banana stems, cacti, acorns and chestnuts, papaya peels, Jatropha curcas seeds and Moringa oleifera [6-12]. This technology is not only low-cost and simple, but also has several advantages such as low initial cost, simplicity of design, ease of operation, insensitivity to toxic substances, and complete removal of pollutants even from dilute solutions [13]. The effectiveness of these coagulants depends on a few parameters such as $\mathrm{pH}$ and dosage in order to achieve high COD and turbidity removal efficiency. Dosage is an essential factor affecting the adsorption process as it shows the adsorption capacity of the coagulants [13]. For example, lead-contaminated water requires $100 \mathrm{mg} \mathrm{L}^{-1}$ of papaya peels to obtain the highest turbidity removal $[8$, $14]$.

Pineapple leaf is one of the alternative plant-based coagulants for water treatment. Pineapple, which is also known as Ananas comosus and belongs to the Bromeliaceae sp., is a perennial plant that ranked third on the list of the most important tropical fruits in the world. Pineapple leaf, which consists of cellulose, hemicellulose and lignin, can provide good thermal and noise insulation $[13,15]$. Pineapple leaf showed tremendous pollutant removal of heavy metal [16]. The decolorization of crystal violet (CV) dyes from textile effluents using pineapple leaf powder (PLP) based on absorption capabilities has also been investigated [17]. However, studies on treatment of polluted pond water to achieve high COD and turbidity removal with low dosage of coagulants are still limited. Moreover, the final treatment of polluted pond water to achieve the standard discharge limit set by the authorities has not been carried out. Thus, this study proposes the treatment of pond water using low dosage of plant-based pineapple leaf coagulant to achieve high COD and turbidity removal to meet the standard discharge limit set by authorities for pond water quality which suitable for recreational use.

\section{MATERIALS AND METHODS}

\subsection{Sample Preparation}

Samples of raw pond water were obtained from a pond in Kota Samarahan area, Sarawak, Malaysia. The water was collected at 3 different sampling points i.e. side, middle, and bottom of the pond. All samples were preserved and stored at temperature less than $4{ }^{\circ} \mathrm{C}$ prior to use. This step was important in order to prevent any biodegradation due to microbial activity which may affect the result of the experiment. $\mathrm{pH}$, total suspended solid (TSS), chemical oxygen demand (COD), turbidity, dissolved oxygen (DO) and biological oxygen demand (BOD) of 
the samples were characterised and analysed based on Standard Methods for the Examination of Water and Wastewater [18].

\subsection{Preparation of Pineapple Leaf Powder}

Pineapple leafs were collected from a farmyard Padawan area, Kuching, Sarawak. The leaves were rinsed with tap water to remove dust, dirt, soil, and any unwanted particles [13]. They were dried in an oven at temperatures ranging between 50 and $80{ }^{\circ} \mathrm{C}$ until the moisture content decreased to below $10 \%$. Dried leaves were chopped into smaller pieces approximately $1-2 \mathrm{~cm}$. The cut leaves were then ground into powder form where the sizes ranged between 1 and $2 \mathrm{~mm}$. Then, the pineapple leaf powder was sieved to separate the larger particles from the powder to ensure that the coagulant readily coagulates with the pollutants. This preparation was conducted according to Idris, et al. [7].

The coagulation experiments were performed using a jar test based on the method performed by Idris, et al. [7]. $500 \mathrm{~mL}$ of pond water was poured into each of 6 beakers. The stirrer was switched on and operated at the 'flash mix' speed of approximately $120 \mathrm{rpm}$ for $1 \mathrm{~min}$ after the addition of the coagulant. The stirrer speed was reduced to slow mixing (30 rpm) for $20 \mathrm{~min}$ and the paddles were withdrawn for a sedimentation process of $30 \mathrm{~min}$. The supernatants were analyzed for $\mathrm{pH}, \mathrm{COD}$, and turbidity removal. The effect of $\mathrm{pH}$ was studied in the range of 2 - 10 and the effect of pineapple leaf dosage was tested in the range of $15-150 \mathrm{mg} \mathrm{\textrm {L } ^ { - 1 }}$. The experiments were repeated up to 3 times to ensure reproducibility of the result and the adjustment of $\mathrm{pH}$ for the pond water samples was controlled by addition of $\mathrm{H}_{2} \mathrm{SO}_{4}$ and $\mathrm{NaOH}$.

\subsection{Analytical Method}

The COD of the raw and treated pond water were determined by HACH COD (DR 2000) analyzer in accordance with $\mathrm{HACH}$ method $(\mathrm{HACH}, 1997)$. The TSS was determined based on Idris, et al. [7]. Turbidity measurement was carried out using the HANNA Model (HI 93703) microprocessor turbidity meter with measurement in FTU. The DO content was determined by using DO meter (Eutech, DO 700). The Biological Oxygen Demand (BOD) and Total Organic Compound (TOC) content were determined based on Standard Methods for the Examination of Water and Wastewater [18].

Table-1. Characteristic of raw pond water in Kota Samarahan area, Sarawak.

\begin{tabular}{c|c|c|c}
\hline Parameters & Raw pond water & Tasik Biru lake water in Sarawak & NWQSM class IIB $^{\mathbf{b}}$ \\
\hline $\mathrm{Ph}$ & 7.21 & 7.76 & $6-9$ \\
\hline $\mathrm{TSS}\left(\mathrm{mg} \mathrm{L}^{-1}\right)$ & 96.67 & 1.40 & 50 \\
\hline $\mathrm{COD}\left(\mathrm{mg} \mathrm{L}^{-1}\right)$ & 136 & 8.22 & 25 \\
\hline Turbidity $\left(\mathrm{FTU}^{-1}\right)$ & 152 & - & 50 \\
\hline $\mathrm{DO}\left(\mathrm{mg} \mathrm{L}^{-1}\right)$ & 6.10 & 5.45 & $5-7$ \\
\hline BOD $\left(\mathrm{mg} \mathrm{L}^{-1}\right)$ & 8 & 1.42 & 3 \\
\hline Note: ${ }^{a} \mathrm{NREB}[19] ;{ }^{b} \mathrm{DOE}[20]$. & &
\end{tabular}

\section{RESULTS AND DISCUSSIONS}

Table 1 shows the characteristics of raw pond water in Kota Samarahan area, Sarawak prior to the jar test coagulation experiment in comparison to Tasik Biru lake water in Sarawak. The lake water quality was used as a benchmark to compare the quality of pond water. It was obvious that the pond water located in Kota Samarahan area, Sarawak was slightly polluted compared to Tasik Biru lake water and NWQSM class IIB [20]. Although the $\mathrm{pH}$ and DO values of the pond water were almost similar to Tasik Biru lake water and within the standards limit of NWQSM, the values of COD, TSS, BOD, and turbidity were still high, which indicated that it would require further treatment. 


\subsection{Effect of Pineapple Leaf Coagulant on COD and Turbidity Removal at Different pH}

The $\mathrm{pH}$ of pond water was determined by conducting the experiment with the addition of a predetermined fixed dosage $\left(25 \mathrm{mg} \mathrm{L}^{-1}\right)$. The dosage value was selected based on a preliminary experiment on dosage effectiveness of pineapple leaf coagulant. $\mathrm{COD}$ and turbidity were monitored in order to determine the appropriate $\mathrm{pH}$ of pond water based on run 1 and run 2 to ensure reproducibility of the results.

Figure $1(\mathrm{a})$ and $(\mathrm{b})$ show the effect of pineapple leaf on removal of COD and turbidity of pond water at different $\mathrm{pH}$ and fixed dosage $\left(25 \mathrm{mg} \mathrm{L}^{-1}\right)$. It showed that the surface charge of pineapple leaf is strongly related to the $\mathrm{pH}$ of the solution. The pineapple leaf mainly consists of polar functional groups such as hydroxyl (-OH) and carbonyl ($\mathrm{C}=\mathrm{O} \&-\mathrm{NH}_{2}$ ) groups that might be involved in coagulation process [13]. The highest percentage of COD removal Figure 1.a was found to range between 55.2 and $63.7 \%$ and turbidity removal Figure 1.b was found to be more than $90.0 \%$, both at $\mathrm{pH}$ 2. At a $\mathrm{pH}$ lower than 4, anionic coagulant is coil up cationic pond water just like nonionic coagulant due to the amide groups (found in pineapple leaf) being replaced by the more inert carboxylate groups (at low $\mathrm{pH}$ ), which reduced the number of hydrogen bonding sites available in the coagulant (pineapple leaf) [21]. This result is almost similar with Shak and Wu [22], who obtained the highest removal using Cassia obtusifolia seed gum coagulant at $\mathrm{pH}$ 3. This is a quite similar observation with Abidin, et al. [9], where the highest turbidity removal percentage was more than $99.0 \%$ at $\mathrm{pH} 3$ by using Jatropha curcas seeds.

Meanwhile, the lowest percentage of COD removal obtained ranged between 15.6 and $23.3 \%$ at $\mathrm{pH}$. This was due to the slight activity of anionic coagulant (pineapple leaf) on cationic pond water. Nevertheless, at $\mathrm{pH} 7$ and 8 (alkaline based), the removal of COD and turbidity were found to increase where the highest COD removal was found to range between 57.8 and $59.0 \%$, and turbidity removal was found to be more than $88.0 \%$, both at pH 8 . As $\mathrm{pH}$ increases, the carboxylate groups of anionic coagulant (pineapple leaf) are ionized Pillai [21], creating a strong electrostatic attraction between the cationic pond water (positively charged) and the pineapple leaf powder surface (negatively charged). This study also showed that the treatment of pond water using pineapple leaf performed better in both acidic and alkaline conditions. This study was in agreement with Neupane, et al. [17], where the maximum adsorption of textile effluents using pineapple leaf powder (PLP) on adsorbents was found at $\mathrm{pH}$ 8. Thus, for further dosage analysis in this study, $\mathrm{pH} 8$ was selected since $\mathrm{pH} 2$ (acidic condition) required additional $\mathrm{H}_{2} \mathrm{SO}_{4}$ treatment, which further increased the cost of treatment.

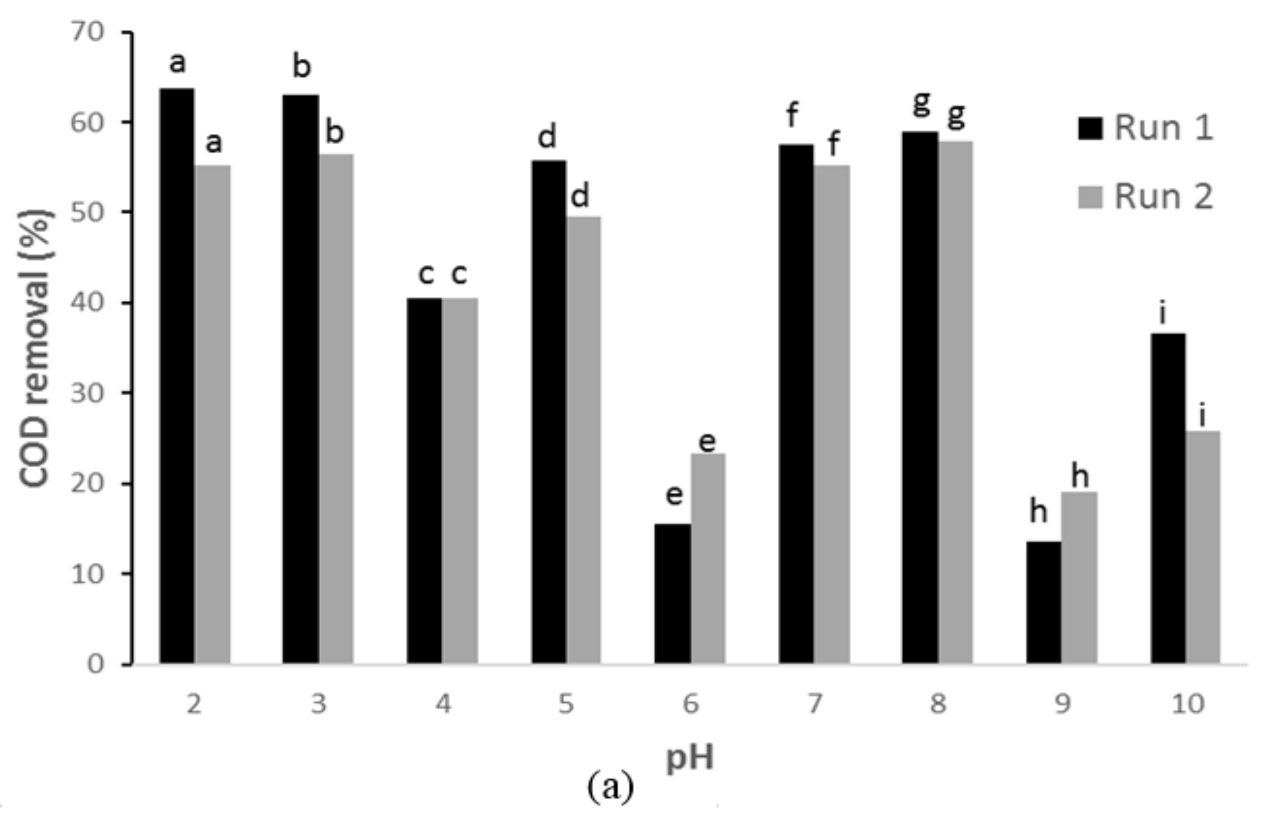




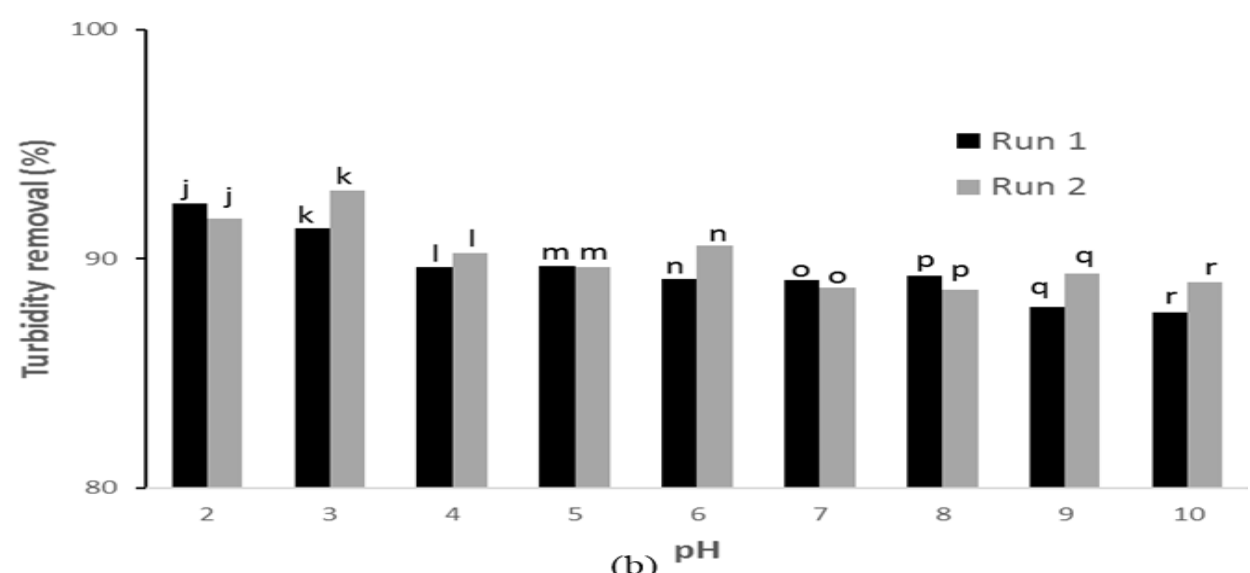

Figure-1. Effect of different $\mathrm{pH}$ of pineapple leaf on removal of (a) COD, and (b) turbidity of pond water at fixed dosage; $\mathrm{N}=3$; letters in common indicate no significant difference $(\mathrm{p}>0.05)$.

\subsection{Effect of Different Dosages of Pineapple Leaf on COD and Turbidity Removal}

The dosage of pineapple leaf was determined by conducting the experiment at a constant $\mathrm{pH}(\mathrm{pH}$ 8). Figure 2 (a) and (b) show the effect of pineapple leaf on removal of COD and turbidity of pond water respectively at different dosages. The highest COD and turbidity removal ranged between $94.1-94.6$ and $88.3-88.4 \%$ respectively, using $50 \mathrm{mg} \mathrm{L} \mathrm{L}^{-1}$ dosage of pineapple leaf coagulant. The final COD and turbidity values ranged between $7.33-8.00 \mathrm{mg} \mathrm{\textrm {L } ^ { - }}$ ${ }^{1}$ and $17.66-17.81$ FTU respectively. The removal percentage decreased as dosage increased $\left(>100 \mathrm{mg} \mathrm{L}^{-1}\right)$ due to an increase the organic load in water, thus resulting in the possibility for undesired and increased microbial activity. Subsequently, it contributes to the increase of COD in an aqueous solution [7]. The treatment of polluted pond water in Kota Samarahan area, Sarawak was successfully carried out using pineapple leaf. The final concentrations of COD and turbidity values were lower compared to the regulatory standards, making the pineapple leaf suitable to be used as a plant-based coagulant for applications in wastewater treatment.

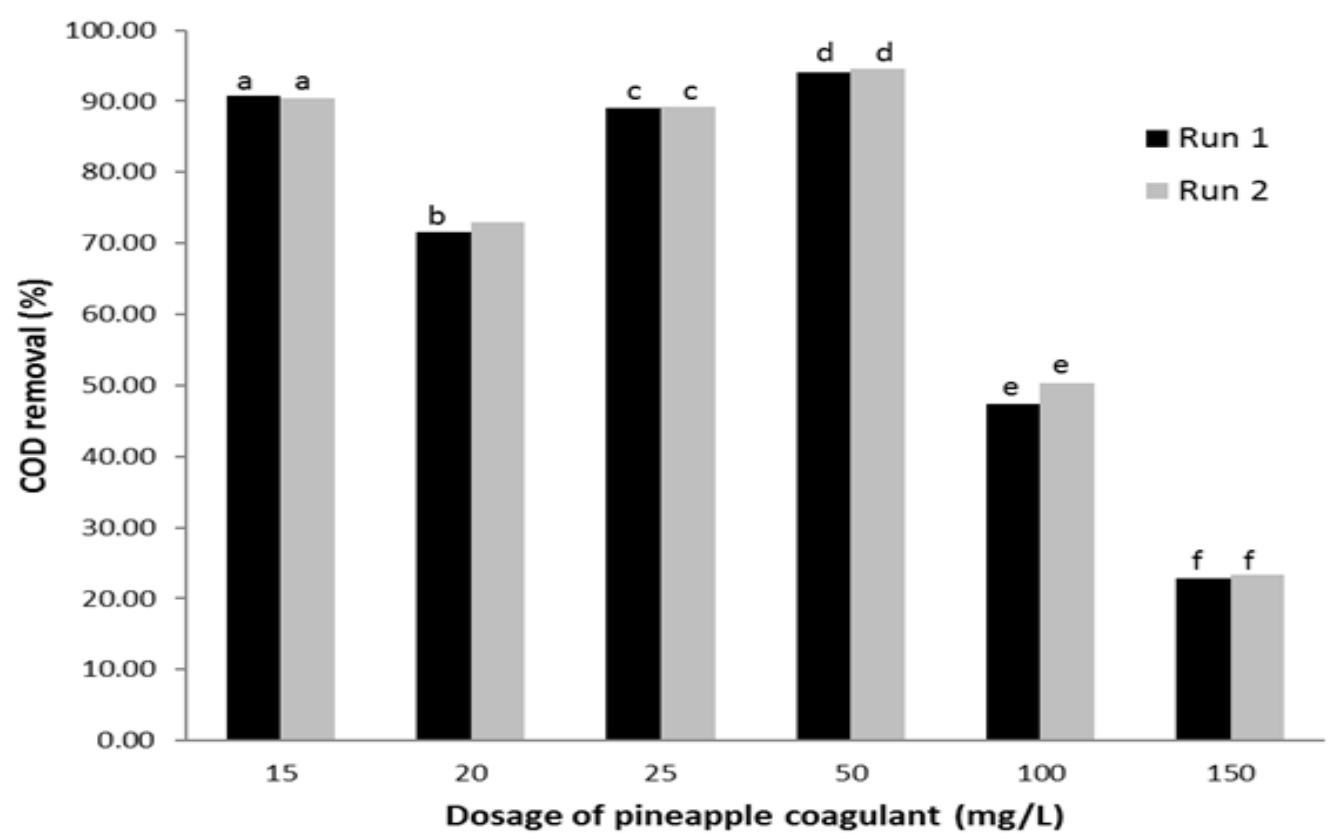

(a) 


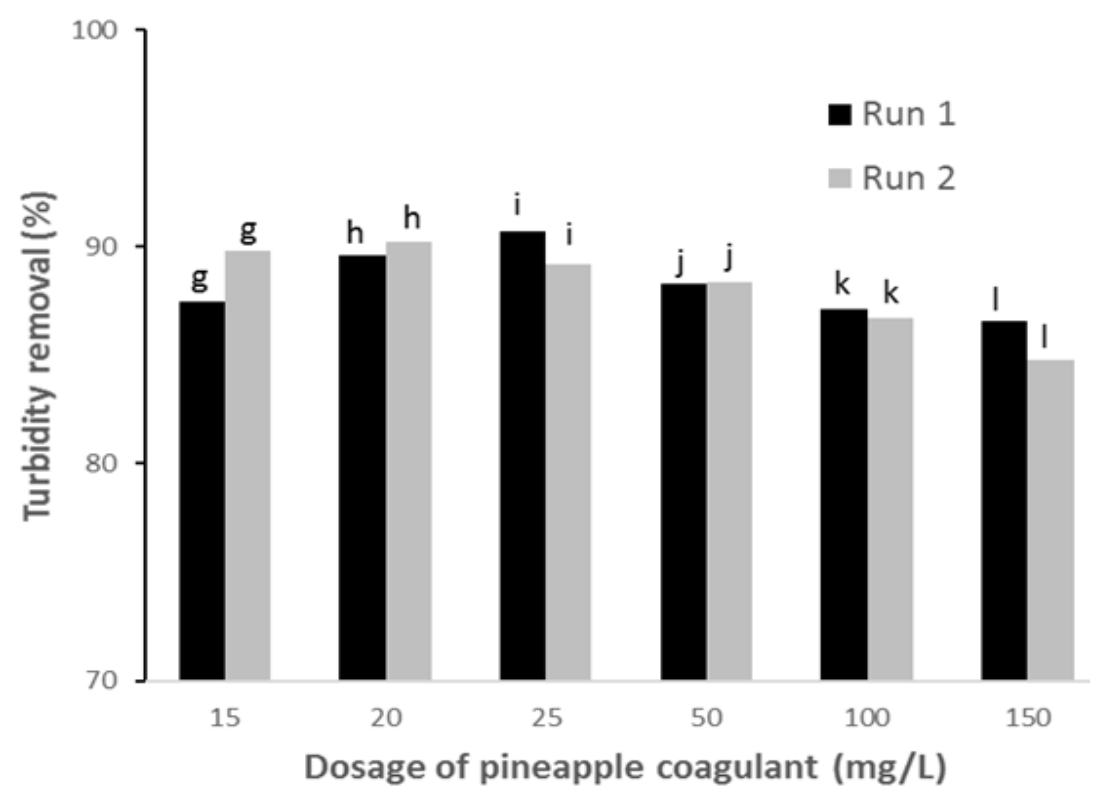

(b)

Figure-2. Effect of different dosages of pineapple leaf on removal of (a) COD, and (b) turbidity of pond water at $\mathrm{pH} 8 ; \mathrm{n}=3$; letters in common indicate no significant difference $(\mathrm{p}>0.05)$.

\subsection{Comparison Studies}

Table 2 shows the comparison of plant-based coagulant dosage treatment using pineapple leaf with other studies. The removal percentage of COD and turbidity obtained in this study ranged between $94.1-94.6$ and $88.3-$ 88.4\%, which are considered high as compared to Kakoi, et al. [23] and Choy, et al. [24], both in acidic solution. As compared to Zhang, et al. [12], in alkaline solution, the COD and turbidity percentage removal in this study were also higher, although a similar dosage was used. Generally, the dosage of pineapple leaf used in this study was relatively low $\left(50 \mathrm{mg} \mathrm{L}^{-1}\right.$ ) as compared to other studies which produced lower COD and turbidity removal. Moreover, the final pH, COD, turbidity, DO, and TSS values of the treated pond water Table 3 were below the standard limits set by the NWQSM class IIB [20]. Nevertheless, the final value of BOD was found to increase from 8 to $18 \mathrm{mg} \mathrm{L}^{-1}$ due to the organic nature of pineapple leaf coagulant, which can increase microbial activity.

Table-2. Comparison of plant based coagulant dosage treatment using pineapple leaf with other studies.

\begin{tabular}{c|c|c|c|c|c|c}
\hline $\begin{array}{c}\text { Types of } \\
\text { wastewater }\end{array}$ & Coagulants & $\begin{array}{c}\text { Optimum } \\
\text { dosage }\end{array}$ & $\begin{array}{c}\text { Optimum } \\
\text { pH }\end{array}$ & $\begin{array}{c}\text { COD } \\
\text { Removal (\%) }\end{array}$ & $\begin{array}{c}\text { Turbidity } \\
\text { Removal (\%) }\end{array}$ & References \\
\hline $\begin{array}{c}\text { Synthetic turbid } \\
\text { water }\end{array}$ & Rice starch & $120 \mathrm{mg} \mathrm{L}^{-1}$ & 4 & - & 50 & $\begin{array}{c}\text { Choy, et al. } \\
{[24]}\end{array}$ \\
\hline $\begin{array}{c}\text { Sewage water } \\
\text { Cactus }\end{array}$ & $50 \mathrm{mg} \mathrm{L}^{-1}$ & 7 & $50-60$ & $80-85$ & $\begin{array}{c}\text { Zhang, et al. } \\
{[12]}\end{array}$ \\
\hline River water & Banana pith & $0.1 \mathrm{~kg} \mathrm{~m}^{-3}$ & 4 & 54.37 & 98.6 & $\begin{array}{c}\text { Kakoi, et al. } \\
{[23]}\end{array}$ \\
\hline $\begin{array}{c}\text { Textile effluent } \\
\text { (crystal violet) }\end{array}$ & Pineapple leaf & $1 \mathrm{~g} \mathrm{~L}^{-1}$ & 8 & - & - & $\begin{array}{c}\text { Neupane, et al. } \\
{[17]}\end{array}$ \\
\hline Pond water & Pineapple leaf & $50 \mathrm{mg} \mathrm{L}^{-1}$ & 8 & $94.12-94.61$ & $88.28-88.38$ & This study \\
\hline
\end{tabular}

Table-3. Comparison of treated pond water in Kota Samarahan area, Sarawak with standard limits.

\begin{tabular}{c|c|c|c}
\hline Parameters & Raw pond water & Treated pond water & NWQSM class IIB $^{\mathbf{b}}$ \\
\hline $\mathrm{pH}$ & 7.21 & 8.3 & $6-9$ \\
\hline COD $\left.(\mathrm{mg} \mathrm{L})^{-1}\right)$ & 136 & $7.3-8.0$ & 25 \\
\hline Turbidity $\left(\mathrm{FTU}^{2}\right)$ & 152 & $17.7-17.8$ & 50 \\
\hline $\mathrm{TSS}\left(\mathrm{mg} \mathrm{L}^{-1}\right)$ & 96.67 & 32 & 50 \\
\hline $\mathrm{DO}\left(\mathrm{mg} \mathrm{L}^{-1}\right)$ & 6.1 & 7.3 & $5.00-7.00$ \\
\hline $\mathrm{BOD}\left(\mathrm{mg} \mathrm{L}^{-1}\right)$ & 8 & 18 & 3
\end{tabular}




\section{CONCLUSION}

A study on the effectiveness of pineapple leaf as a plant-based coagulant on pond water was successfully carried out. It showed a significant COD and turbidity percentage removal which ranged between $94.1-94.6$ and $88.3-$ $88.4 \%$ respectively at $\mathrm{pH} 8$ using low dosage of pineapple leaf coagulant $\left(50 \mathrm{mg} \mathrm{L}^{-1}\right)$. The final values of COD and turbidity were found to be in the range of $7.3-8.0 \mathrm{mg} \mathrm{L}^{-1}$ and $17.66-17.81$ FTU respectively. The results found higher percentage of COD and turbidity removal compared to other studies using different plant-based coagulants with higher or similar dosages. Moreover, the final $\mathrm{pH}$, COD, turbidity, DO, and TSS values of the treated pond water were below the standard limits set by the NWQSM class IIB, which represents water bodies suitable for recreational use with body contact [20]. The newly-studied plant-based coagulant from pineapple leaf biomass successfully reduced COD and turbidity of treated pond water to achieve water pond quality, and is expected to be suitable for treatment of other types of wastewater from secondary industrial plants.

Funding: The authors gratefully acknowledge the research grant provided by Universiti Teknologi MARA, Sarawak Branch (Grant No. 600-RMU/DNA 5/3 (3/2016)).

Competing Interests: The authors declare that they have no competing interests.

Acknowledgement: The authors thank Faculty of Applied Sciences and Faculty of Chemical Engineering, College of Engineering, Universiti Teknologi MARA, Sarawak Branch for the technical support towards this research.

\section{REFERENCES}

[1] Population Reference Bureau, "2016 world population data sheet. Retrieved from: https://www.herodote.net/Textes/population-2016.pdf. [Accessed Nov. 09, 2016]," 2016.

[2] C. Munusami, J. Othman, and S. M. Ismail, "Using choice modelling to reveal household demand for wastewater treatment in Malaysia," APCBEE Procedia, vol. 10, pp. 64-68, 2014.

[3] L. Serrano and M. E. DeLorenzo, "Water quality and restoration in a coastal subdivision stormwater pond," Journal of Environmental Management, vol. 88, pp. 43-52, 2008.Available at: https://doi.org/10.1016/j.jenvman.2007.01.025.

[4] T. Lawson, Fundamental of aquacultural engineering. Boston, MA, USA: Springer Science \& Business Media, 2013.

[5] Y. J. Chan, M. F. Chong, C. L. Law, and D. G. Hassell, "A review on anaerobic-aerobic treatment of industrial and municipal wastewater," Chemical Engineering Journal, vol. 155, pp. 1-18, 2009.Available at: https://doi.org/10.1016/j.cej.2009.06.041.

[6] M. Sćiban, M. Klašnja, M. Antov, and B. Skrbić, "Removal of water turbidity by natural coagulants obtained from chestnut and acorn," Bioresource Technology, vol. 100, pp. 6639-6643, 2009.Available at: https://doi.org/10.1016/j.biortech.2009.06.047.

[7] J. Idris, A. Md Som, M. Musa, K. H. Ku Hamid, R. Husen, and M. N. Muhd Rodhi, "Dragon fruit foliage plant-based coagulant for treatment of concentrated latex effluent: Comparison of treatment with ferric sulfate," Journal of Chemistry, vol. 2013, pp. 1-7, 2013.

[8] S. Abbaszadeh, S. R. W. Alwi, C. Webb, N. Ghasemi, and I. I. Muhamad, "Treatment of lead-contaminated water using activated carbon adsorbent from locally available papaya peel biowaste," Journal of Cleaner Production, vol. 118, pp. $210-$ 222, 2016.Available at: https://doi.org/10.1016/j.jclepro.2016.01.054.

[9] Z. Z. Abidin, N. S. M. Shamsudin, N. Madehi, and S. Sobri, "Optimisation of a method to extract the active coagulant agent from Jatropha curcas seeds for use in turbidity removal," Industrial Crops and Products, vol. 41, pp. 319-323, 2013.Available at: https://doi.org/10.1016/j.indcrop.2012.05.003.

[10] H. Alwi, J. Idris, M. Musa, and K. H. Ku Hamid, "A preliminary study of banana stem juice as a plant-based coagulant for treatment of spent coolant wastewater," Journal of Chemistry, vol. 2013, pp. 1-7, 2013.

[11] H. M. De Paula, M. S. de Oliveira Ilha, and L. S. Andrade, "Concrete plant wastewater treatment process by coagulation combining aluminum sulfate and Moringa oleifera powder," Journal of Cleaner Production, vol. 76, pp. 125130, 2014.Available at: https://doi.org/10.1016/j.jclepro.2014.04.031. 
[12] J. Zhang, F. Zhang, Y. Luo, and H. Yang, "A preliminary study on cactus as coagulant in water treatment," Process Biochemistry, vol. 41, pp. 730-733, 2006.Available at: https://doi.org/10.1016/j.procbio.2005.08.016.

[13] S. Chowdhury, S. Chakraborty, and P. Saha, "Biosorption of basic green 4 from aqueous solution by Ananas comosus (pineapple) leaf powder," Colloids and Surfaces B: Biointerfaces, vol. 84, pp. 520-527, 2011.Available at: https://doi.org/10.1016/j.colsurfb.2011.02.009

[14] B. Ramavandi, "Treatment of water turbidity and bacteria by using a coagulant extracted from Plantago ovata," Water Resources and Industry, vol. 6, pp. 36-50, 2014.

[15] R. Arib, S. Sapuan, M. Ahmad, M. Paridah, and H. K. Zaman, "Mechanical properties of pineapple leaf fibre reinforced polypropylene composites," Materials \& Design, vol. 27, pp. 391-396, 2006.Available at: https://doi.org/10.1016/j.matdes.2004.11.009.

[16] D. D. M. Dacera and S. Babel, "Heavy metals removal from contaminated sewage sludge by naturally fermented raw liquid from pineapple wastes," Water Science and Technology, vol. 56, pp. 145-152, 2007.Available at: https://doi.org/10.2166/wst.2007.680.

[17] S. Neupane, S. Ramesh, R. Gandhimathi, and P. Nidheesh, "Pineapple leaf (Ananas comosus) powder as a biosorbent for the removal of crystal violet from aqueous solution," Desalination and Water Treatment, vol. 54, pp. 2041-2054, 2015.Available at: https://doi.org/10.2166/wst.2007.680.

[18] APHA, Standard methods for the examination of water and wastewater, 21 st ed. Washington, DC: American Public Health Association, 2005.

[19] NREB, Environment quality report 2006. Sarawak: Natural Resources and Environmental Board (NREB), 2006.

[20] DOE, "River water quality monitoring, Water quality Index (WQI) and Interim National Water Quality Standards for Malaysia (INWQSM). Retrieved from: https://www.doe.gov.my/portalv1/en/info-umum/pemantauan-kualiti-airsungai/280. [Accessed Nov. 11, 2016]," 2016.

[21] J. Pillai, "Flocculants and coagulants: The keys to water and waste management in aggregate production. Stone review, Nalco Company. Retrieved from: http://www.aniq.org. [Accessed Jul. 09, 2017]," 1997.

[22] K. P. Y. Shak and T. Y. Wu, "Coagulation-flocculation treatment of high-strength agro-industrial wastewater using natural Cassia obtusifolia seed gum: Treatment efficiencies and flocs characterization," Chemical Engineering Journal, vol. 256, pp. 293-305, 2014.

[23] B. Kakoi, J. W. Kaluli, P. Ndiba, and G. Thiong'o, "Banana pith as a natural coagulant for polluted river water," Ecological Engineering, vol. 95, pp. 699-705, 2016.

[24] S. Y. Choy, K. N. Prasad, T. Y. Wu, M. E. Raghunandan, and R. N. Ramanan, "Performance of conventional starches as natural coagulants for turbidity removal," Ecological Engineering, vol. 94, pp. 352-364, 2016.Available at: https://doi.org/10.1016/j.ecoleng.2016.05.082.

Views and opinions expressed in this article are the views and opinions of the author(s), Journal of Asian Scientific Research shall not be responsible or answerable for any loss, damage or liability etc. caused in relation to/arising out of the use of the content. 